\title{
EMF Pollution - Causes, Effects and Protection
}

\author{
R.Velavan, S.Bharanidharan, B. Sheeba
}

\begin{abstract}
In modern day's high tech world, all of us are constantly experiencing EM radiation from almost all sources. Each and every source introduce its own EMF. At this very moment as you are reading this paper, you are probably being exposed to many electro-magnetic fields. The situation is no different while we are at play, travelling, at work, reposing at home, and even sleeping on bed. Practically there is an increase in EMR pollution with the increase in every new invention. EMR of all frequencies serve as one of the fastest growing and most common environmental impacts, about which speculation and anxiety are growing. The digital communication devices which we use emit digital pulsed radio-frequency EMFs which are perhaps one of the most harmful kind for human health. In today's world use of cell phone has become ubiquitous with an estimated subscription of 6.9 billion globally. In modern day telecommunication cell phones play a very crucial role. It is not astonishing that the level of invisible electromagnetic pollution on our planet is tremendously high. As a result it is essential to examine, discern and check any possible impact on public health. The leading aim of this paper is to examine the harmful impacts of the electromagnetic radiation, survey the regulations which are in place to keep a check on the levels of radiations and to suggest a few daily habits which will help to reduce one's exposure to such harmful radiations.
\end{abstract}

Keywords : Electromagnetic field (EMF), Electromagnetic radiation (EMR), Electromagnetic compatibility (EMC), Interference (EMI)

\section{INTRODUCTION}

Electromagnetic compatibility is defined as the capability of the systems and devices to operate in their electromagnetic environment without debilitating in their functions. EMC is the idea of enabling electronic devices to operate without mutual interference - Electromagnetic Interference (EMI) when they are operated in close proximity to each other. [20],[ 22], [24]

All electronic circuits have a high possibility of picking up and radiating undesired electrical interferences which may

hinder the working of the circuits. [8],[ 10] ,[12] Electromagnetic compatibility(EMC) ensures that the operation of one device does not impact the surrounding electromagnetic environment to such an extent that the functions of other systems and devices are adversely affected. Usage of electronic devices in military applications was one of the early and notable concerns of the effects of EMI on

Revised Manuscript Received on July 22, 2019.

Dr.R.Velavan, Deparment of Physics, Bharath Institute of Higher Education and Research, Tamilnadu,India. Email: prvelavan@gmail.com

Dr.S.Bharanidharan, Deparment of Physics, Bharath Institute of Higher Education and Research, Tamilnadu,India. Email: bharani.dharan0@gmail.com

B.Sheebha, Deparment of Physics, Bharath Institute of Higher Education and Research, Tamilnadu,India. Email: bsheeba1 @ gmail.com electronic systems. With the rise in emphasis on nuclear weapons after the Second World War the effects of electronic pulse generated by an explosion and high powered radar systems on equipment became a concern. Some of the ill effects it had on the surrounding devices were that it could set false triggers and sometimes even damage the device. During the 1970s the use of logic circuitry grew rapidly which led to higher switching speeds. 3 .

\section{MATERIALS AND METHODOLOGY}

The electromagnetic fields experienced from a strong radiation source that is far away is much lesser compared to the electromagnetic fields experienced from a weak radiation source that is close by. The strongest EMF which we are experiencing is probably coming from a digital phone, computer or household appliance which are quite close to us.

\section{RESULTS AND DISCUSSION}

- It is advisable for the users of mobile phone to maintain at least $30-40 \mathrm{~cm}$ distance between phone and body as the radiation power decreases rapidly with increasing distance from the cell. Hence, someone holding the head set next to his head will be exposed to much larger amount of radiofrequency fields than someone who is holding it farther apart.

- Another important way to limit one's exposure to such radiations is to reduce the number and length of calls. Cell phones should be positioned in such a way that the antenna of the cell is facing away from us. [25],[27],[29]

- Different types of fabrics are available which can be used to shield oneself from the harmful electromagnetic fields and radiations. Mesh type shielding fabrics are used for canopies, curtains, enclosures. Shielding fabrics with a natural feel and look made with bamboo fibre and silver are used for- bedding, drapes, clothing, grounding, tents. [31],[33],[35]

- We should avoid using phone when its battery is low or even when the signal reception is poor because they emit more radiation. On the other hand we should use them in areas of good reception where theytransmit signals at reduced power. We should also avoid using cell phone in elevators, cars, trains and planes because they radiate and draw more power in a metal enclosed environment.

- Mainly on airplanes and in hospitals mobile phones are often prohibited as the RF signals emitted by them disrupt the working of navigation systems and electro-medical devices [19],[21],[23]

- Clocks which are powered by battery are preferred and we should make sure that the extension cords do not spread 
under or around the bed and also proper care must be taken to avoid electric blankets and wired mattress warmers. [13], [15], [ 17]

- Use of an Ethernet cord instead of a wireless router to connect to the internet should be highly discouraged. Using wired computer peripherals like mouse, keyboard and printers are good options. It is better to disconnect Wi-Fi enabled devices, before going to bed and house the router away from children's room and desk.

- While choosing electronic devices like TV, proper precaution must be taken in choosing a LCD in place of old cathode ray tube models or plasma models as the amount of radiation from the LCD is much lesser compared to others.

- Other materials which can be used as fabric to shield from electromagnetic radiation are -alternative layer of pure cotton and silver, surgical stainless steel knitted fabric, a polyester substrate, plated with nickel and copper, etc [6].

\section{The perils of electromagnetic radiation by cell phones}

Mobile phones are considered dangerous as they emit powerful EMFs and are held close to the head or body for long duration of time [2].

- Electromagnetic radiations emitted from phone's antenna is very harmful.

- Radiation from cell phone antenna penetrates up to 2 inches into the adult brain depending on the duration of use of cell phone.

- Mobile phones cause heating up of biological tissues and also have non-thermal effects.

- Experiments have proven that poor rapid eye movement sleep causes impaired learning and memory which is linked to exposure to EMR when people sleep with a cell phone close to bed.

- Brainwaves are altered approximately $70 \%$ of the time the cell phone is held next to the head.

\section{Effects of Fluorescent and LED lights}

Fluorescent tubes and light bulbs internally produce ultraviolet light. Normally visible light is obtained from this by a phosphor film present inside a protective coating. Due to faulty manufacturing or mishandling of the film, the film might crack which leads to escape of ultraviolet light at levels that could cause sunburn or even skin cancer. The pineal gland produce a reduced quantity of melatonin and people

observe poor sleeping periods due to failure of human's biological clock when exposed to blue light emitting wavelengths of 400-500 nanometers. [1],[3],[5]

\section{Safe levels of electromagnetic radiation}

The US Federal Communications Commission (FCC) have set standards for the specific absorption rate (SAR) and those levels which are above these set standards are considered to be harmful. Exposure levels of up to a SAR level of $4 \mathrm{~W} / \mathrm{kg}$ is considered to be safe level to radio frequency and microwave radiation, which is considered to be the threshold level. Beyond this level body starts experiencing harmful thermal effects due to energy absorption.0.4 W/kg SAR is the recommended protection guidelines keeping in mind a factor of ten to be on a safer side. Eastern European countries and Russia set different SAR thresholds which are lower than western countries. Different countries set different SAR standards especially with respect to low exposure levels [3].

\section{CONCLUSION}

The entire population is susceptible to various degrees of radiation, and the increasing level of EMR is directly dependent on the advancement in technology. Hence we should all act collectively to minimize further growth. There is an increase in the number of situations related to negative health effects due to exposure to EMFs which is becoming more clear and difficult to ignore. Unless the public dedicate considerable amount of time and take initiative to learn and educate others as well about EMF and EMR, it is hard to find cleaner and healthier alternatives. The average level of EMF we experience today is estimated to be fifty times greater than what our parents experienced at the same age. Should today's children experience fifty times more electromagnetic fields than we do now? Raphael Siket once rightly said "Improving

the air you breathe, the water you drink and the products you use, Benefits the life you lead, the generations to come and the planet as a whole". [20],[22], [24]

\section{REFERENCES}

1 M., Jayaprakash P., Kumari C.R.T., Vinitha G., Caroline M.L., Growth, spectral, linear and nonlinear optical characteristics of an efficient semiorganic acentric crystal: L-valinium L-valine chloride, 2017 Physica B: Condensed Matter, V-511, PP -1-9,

2) Sangeetha P., Jayaprakash P., Nageshwari M., Rathika Thaya Kumari C., Sudha S., Prakash M., Vinitha G., Lydia Caroline M., Growth and characterization of an efficient new NLO single crystal L-phenylalanine D-methionine for frequency conversion and optoelectronic applications, 2017, Physica B: Condensed Matter, V-525, PP-164-174

3) Peer Mohamed M., Jayaprakash P., Nageshwari M., Rathika Thaya Kumari C., Sangeetha P., Sudha S., Mani G., Lydia Caroline M., Crystal growth, structural, spectral, thermal, linear and nonlinear optical characterization of a new organic nonlinear chiral compound: L-tryptophan-fumaric acid-water (1/1/1) suitable for laser frequency conversion, 2017, Journal of Molecular Structure, V-1141, PP-551-562

4) Jayaprakash P., Sangeetha P., Kumari C.R.T., Caroline M.L., Investigation on the growth, spectral, lifetime, mechanical analysis and third-order nonlinear optical studies of L-methionine admixtured D-mandelic acid single crystal: A promising material for nonlinear optical applications, 2017, Physica B: Condensed Matter, V-518, PP-1-12

5) Nageshwari M., Kumari C.R.T., Vinitha G., Mohamed M.P., Sudha S., Caroline M.L., Crystal growth, structural, spectral, thermal, dielectric, linear and nonlinear optical characteristics of a new organic acentric material: L-Methionine-Succinic acid (2/1), 2018, Journal of Molecular Structure, V-1155, PP-101-109

6) Jayaprakash P., Sangeetha P., Kumari C.R.T., Baskaran I., Caroline M.L., Growth and characterization of 1-asparagine monohydrate admixtured dl-mandelic acid nonlinear optical single crystal, 2017, Journal of Materials Science: Materials in Electronics, V-28, PP-18787-18794

7) Rathika Thaya Kumari C., Nageshwari M., Jayaprakash P., Sangeetha P., Sudha S., Lydia Caroline M., Investigation on growth, optical, thermal, mechanical, 
dielectric, LDT studies of sulphanilic acid monohydrate: A promising third-order nonlinear optical material, 2017, Journal of Nonlinear Optical Physics and Materials, V-26, I - 2,

8) Thaya Kumari C.R., Nageshwari M., Raman R.G., Caroline M.L., Crystal growth, spectroscopic, DFT computational and third harmonic generation studies of nicotinic acid, 2018, Journal of Molecular Structure, V-1163, PP-137-146

9) Nageshwari M., Kumari C.R.T., Sangeetha P., Vinitha G., Caroline M.L., Third order nonlinear optical, spectral, dielectric, laser damage threshold, and photo luminescence characteristics of an efficacious semiorganic acentric crystal: L-Ornithine monohydrochloride, 2018, Chinese Journal of Physics, V-56, I - 2, PP-502-519

10) Kumari C.R.T., Jayaprakash P., Nageshwari M., Mohamed M.P., Sangeetha P., Caroline M.L., Growth, optical, photoluminescence, dielectric, second and third order nonlinear optical studies of benzoyl valine acentric crystal, 2017, Molecular Crystals and Liquid Crystals, V-658,I - 1, PP-186-197

11) Rathika Thaya Kumari C., Nageshwari M., Sudha S., Lydia Caroline M., Mani G., Influence of uranyl on the growth, linear, laser damage threshold and nonlinear optical studies on potential nonlinear optical single crystal: L-Alanine, 2015, Journal of Chemical and Pharmaceutical Sciences, V-2015-October,PP-166-170,

12) Rathika Thaya Kumari C., The detailed study ontwo dimensional hydrogen atom, 2013, Middle - East Journal of Scientific Research, V-17,I-12, PP-1900-1902

13) Rathika Thaya Kumari C., Theoretical study about the measuremen of ultrasonic velocity using different methods, 2013, Middle - East Journal of Scientific Research, V-17, PP-12-

14) Mukunthan A., Rathika Thaya Kumari C., Nageshwari M., Prakash D., The effect of super saturation and crystal growth kinetics of L-arginine per chlorate, 2013, Middle - East Journal of Scientific Research, V-17,I-12 PP-1825-1827

15) Sree Latha R., Vijayaraj R., Azhagiya Singam E.R., Chitra K., Subramanian V., 3D-QSAR and Docking Studies on the HEPT Derivatives of HIV-1 Reverse Transcriptase, 2011, Chemical Biology and Drug Design, V-78,I-12, PP-1816-1819

16) Sree Latha R., Vijayaraj R., Padmanabhan J., Azhagiya Singam E.R., Chitra K., Subramanian V., 3D-QSAR studies on the biological activity of juvenile hormone mimetic compounds for Culex pipiens Larvae, 2013, Medicinal Chemistry Research, V-22, I-12,PP-418-426

17) Subashini G.,A simple proof on coloring of dominated special graphs, Indian Journal of Science and Technology,V-7,I-,PP-5-6,Y-2014

18) Ramya N.,On coloring of corona graphs, Indian Journal of Science and Technology,V-7,I-SUPPL2,PP-9-11,Y-2014.

19) Ramya N., On colourings of wheel graph (Wn), Indian Journal of Science and Technology,V-7,I-,PP-72-73,Y-2014.

20) Ramya N., On star chromatic number of P3 (n), Indian Journal of Science and Technology,V-7,I-,PP-7-8, Y-2014.

21) Vijayaragavan S.P.,An investigative expert that's general FBG sensors,International Journal of Mechanical Engineering and Technology,V-8,I-8,PP-1500-1505,Y-2017

22) Vijayaragavan S.P.,Equalization routing protocol for Wi-Fi sensor strategy,International Journal of Mechanical Engineering and Technology,V-8,I-8,PP-1662-1666,Y-2017

23) Karthik B., Kiran Kumar T.V.U., Vijayaragavan P., Bharath Kumaran E.,Design of a digital PLL using 0.35 ̂́1/4m CMOS technology,Middle East Journal of Scientific Research,V-18,I-12,PP-1803-1806,Y-2013

24) Kanniga E., Selvaramarathnam K., Sundararajan M.,Kandigital bike operating system,Middle - East Journal of Scientific Research, V

25) Jasmin M., Vigneshwaran T., Beulah Hemalatha S.,Design of power aware on chip embedded memory based FSM encoding in FPGA,International Journal of Applied Engineering Research,V-10,I-2,PP-4487-4496,Y-2015

26) Jasmin M.,Optimization techniques for low power VLSI circuits,Middle - East Journal of Scientific Research,V-20,I-9,PP-1082-1087,Y-2014

27) Jasmin M., Vigneswaran T.,Fuzzy controller for error control of on Chip communication,2017 International Conference on Algorithms, Methodology, Models and Applications in Emerging Technologies, ICAMMAET 2017,V-2017-January,I-,PP-1-5,Y-2017

28) Ramya N., On star chromatic number of $P 3$ (n),Indian Journal of Science and Technology,V-7,I-,PP-7-8,Y-2014.

29) Cauchy Multiplication of Euler Summable series in Ultrametric Fields, PNNVS R.Deepa Commentationes Mathematicae 53 ((1)), 73 79

30) Kumaravel A., Meetei O.N.,An application of non-uniform cellular automata for efficient cryptography,Indian Journal of Science and Technology,V-6,I-SUPPL5,PP-4560-4566,Y-2013
31) Kumaravel A., Meetei O.N.,An application of non-uniform cellular automata for efficient cryptography,2013 IEEE Conference on Information and Communication Technologies, ICT 2013,V-,I-,PP-1200-1205,Y-2013

32) Kumarave A., Rangarajan K.,Routing alogrithm over semi-regular tessellations,2013 IEEE Conference on Information and Communication Technologies, 2013,V-,I-,PP-1180-1184,Y-2013

33) Gopinath S., Sundararaj M., Elangovan S., Rathakrishnan E.,Mixing characteristics of elliptical and rectangular subsonic jets with swirling co-flow,International Journal of Turbo and Jet Engines, V-32,I-1,PP-73-83,Y-2015

34) Rathika Thaya Kumari C., A brief review on the impacts of tropospheric ozone on biological systems, 2013, Middle - East Journal of Scientific Research, V-17,I-12, PP-1820-1824

35) Mukunthan A., Rathika Thaya Kumari C., Nageshwari M., Prakash D., A brief review on the applications of fluorescent spectroscopy in biomedical diagnosis, 2013, Middle - East Journal of Scientific Research, V-17,I-12, PP-1828-1830

\section{AUTHORS PROFILE}

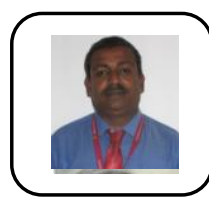

Dr.R.Velavan Associate Professor, Department of Physics, Bharath Institute of Higher Education and Research, Chennai, India

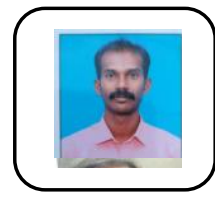

Dr.S.Bharanidharan Associate Professor, Department of Physics, Bharath Institute of Higher Education and Research, Chennai, India

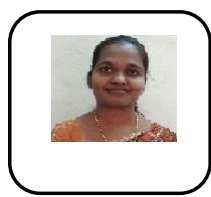

B.Sheeeba, Assistant Professor, Department of Physics, Bharath Institute of Higher Education and Research, Chennai, India 